\title{
RISK ASSESSMENT OF HEAVY METALS IN SOILS CONTAMINATED BY SMELTING WASTE FOR THE PERSPECTIVE OF CHEMICAL FRACTION AND SPATIAL DISTRIBUTION
}

\author{
Xiaoxi ZENG ${ }^{1}$, Qiming $\mathrm{CHEN}^{1}$, Qin TAN ${ }^{1}$, Hong XU1ㄴ, Wen $\mathrm{LI}^{1}{ }^{1}{ }^{*}$, Sheng YANG ${ }^{3}$, \\ Jianhui $\mathrm{WANG}^{4}$, Jiali REN ${ }^{2}$, Feijun $\mathrm{LUO}^{2}$, Jianxing TANG ${ }^{1}$, Ling $\mathrm{WU}^{1}$, \\ Yuanke $\mathrm{ZHANG}^{1}$, Dongmin $\mathrm{LIU}^{4}$ \\ ${ }^{1}$ Key Laboratory of Biological Nanomaterials and Devices, College of Life Sciences and Chemistry, \\ Hunan University of Technology, 412007 Zhuzhou, P.R. China \\ ${ }^{2}$ Hunan Province Key Laboratory of Edible forestry Resources Safety and Processing Utilization, \\ Hunan Key Laboratory of Processed Food for Special Medical Purpose, National Engineering Laboratory \\ for Deep Process of Rice and Byproducts, College of Food Science and Engineering, \\ Central South University of Forestry and Technology, 410004 Changsha, China \\ ${ }^{3}$ School of Energy Science and Engineering, Central South University, 410083 Changsha, P.R. China \\ ${ }^{4}$ School of Chemistry and Food Engineering, Changsha University of Science and Technology, \\ 410114 Changsha, P.R. China
}

Received 28 February 2020; accepted 01 December 2020

\author{
Highlights \\ The contents of heavy metal fractions $(\mathrm{Pb}$ and $\mathrm{Cd})$ decrease with the soil depth. \\ Three heavy metals $(\mathrm{Cr}, \mathrm{Cd}$, and $\mathrm{Pb})$ were dominated by Fe-Mn oxides fraction. \\ $>$ In this smelter, $\mathrm{Cr}$ mainly geogenic background sources, $\mathrm{Cd}$ and $\mathrm{Pb}$ derived from human activities. \\ To those areas, provide some initial data on the heavy metal pollution remediation.
}

\begin{abstract}
The heavy metals contamination in soil has attracted increasing attention. In this study, the main objective was to determine three heavy metals $(\mathrm{Cd}, \mathrm{Pb}$, and $\mathrm{Cr})$ of soils contaminated by smelting waste, and to evaluate pollution risk. The $\mathrm{Pb}(15.48 \mathrm{mg} / \mathrm{kg})$ and $\mathrm{Cd}(311.39 \mathrm{mg} / \mathrm{kg})$ mean concentrations exceeded the national standard, while $\mathrm{Cr}(48.60 \mathrm{mg} / \mathrm{kg})$ concentration did not exceed. The Heavy metal fractions analysis showed that three heavy metals were dominated by Fe$\mathrm{Mn}$ oxides fraction (Fe-Mn). The correlation and cluster analysis indicated that there was significant correlation between $\mathrm{Cd}$ and $\mathrm{Pb}(0.55<\mathrm{r}<0.96)$, while $\mathrm{Cr}$ was not correlation to $\mathrm{Cd}$ and $\mathrm{Pb}$. The environmental pollution of heavy metals was assessed by the ratio of secondary phase and primary phase $(R S P)$. The result showed that $R S P$ values of $\mathrm{Cd}, \mathrm{Pb}, \mathrm{and} \mathrm{Cr}$ range from 13.05-54.28, 16.11-4.97 and 1.61-52.33, which indicated soil was serious contaminated by them. These results showed that smelting waste discharge led to this smelter soil being seriously contaminated by multiple heavy metals which have a tendency to transport and accumulate into deep soil due to their high fractional transformation.
\end{abstract}

Keywords: heavy metals, smelting waste, spatial distribution, $R S P$.

\section{Introduction}

With urbanization and industrialization, soil pollution has become more serious, and heavy metals are major pollution element due to their toxicity and accumulation. Heavy metals not only threaten humans' health, but also affect plant metabolism (Cao et al., 2018). For example, people who exposure to $\mathrm{Cd}, \mathrm{Cr}$, and $\mathrm{Pb}$ environment long-term would more easily suffer human fatal diseases (Lu et al., 2018). Cd can affect plant active oxygen metabolism which induce physiological disorder of plant (Dong et al., 2010). The soil around smelter was polluted by smelting waste that produced during smelting process (including wastewater, soild waste and waste gas), which enrich heavy metals in soil greatly (Cai et al., 2015). Zhang

*Corresponding author. E-mail: liwenjoha@yahoo.com 
et al. (2019) studied pollution characteristics and ecotoxicity in soil nearby silver smelting site, and found soil was heavily polluted by $\mathrm{As}, \mathrm{Cd}, \mathrm{Pb}, \mathrm{Zn}$, and $\mathrm{Cu}$. Therefore, soil remediation around smelters has attracted increasing attention, where soil pollution can be avoided by removing heavy metals from smelting waste. At present, methods of removing heavy metals from smelting waste mainly include physical, chemical and biological methods (Steliga \& Kluk, 2020; Zhu et al., 2015). Mo et al. (2018) summarized the latest developments in removing heavy metals from wastewater by agro-industrial waste as adsorbents, and thought it was a promising and effective technology. Ananya and Manan (2020) reviewed various treatment methods for decreasing ecotoxicological effects of wastewater, and thought bioremediation was the most sustainable and economically viable option. However, the soils that have been contaminated by smelting waste require comprehensive investigation then be given appropriate remediation methods.

Zhuzhou is the second largest city in Hunan province and is an industrial city beside the Xiangjiang River. There are more than one hundred factories in this city, including smelters, chemical factories, dyehouses, electroplating factories. The municipal sewage and industrial wastewater were discharged into the Xiang River, resulting in serious pollution, especially soil heavy metals pollution (Li et al., 2018). In the last ten years, soil pollution has been treated with varying ways in Zhuzhou (Wei et al., 2018). However, the problem is still serious because heavy metals are easy to transfer and diffuse in soil, water, and air (Nagajyoti et al., 2010). It is of great urgency to understand the pollution characteristics of heavy metals in the soil, and select an appropriate remediation technology. In previous experiments, we have detected heavy metals content in soil around Zhuzhou smelter beside Xiangjiang River (Wei et al., 2013). In this study, spatial distribution of three heavy metals $(\mathrm{Cd}, \mathrm{Cr}$, and $\mathrm{Pb})$ in contaminated soils by smelting waste beside Xiangjiang River was investigated to further understand the characteristics of soil pollution. The aims of this study were (1) to identify fractions distribution characteristics of heavy metals, (2) to evaluate degree of soil pollution by the ratio of secondary phase and primary phase $(R S P)$, and (3) to provide those areas with some initial data on heavy metal pollution remediation.

\section{Materials and methods}

\subsection{Collection of sample}

The soil sample was taken from a smelter by the Xiangjiang River in Zhuzhou (Figure 1). In this area, the soil here is yellow red soil, and vegetation is bushes, and annual average precipitation and temperature are about $1471 \mathrm{~mm}$ and $17.2^{\circ} \mathrm{C}$, respectively. In addition, the spread of smelting waste easy to the surrounding residential areas and Xiang River because of northwest wind in winter and south wind in summer in this area. This study selected four sites ( $A$ is located in the smelter, B and D are located by Xiang River, and $\mathrm{C}$ is located next to residential area) to understand extent and scope of soil pollution in this area. Each sampling site included five different profile soil samples $(0-100 \mathrm{~cm})$. The column soil was collected using cylindrical iron sampler at each depth interval $(20 \mathrm{~cm})$, removed stones and uniformly mixed, then taked 1-2 $\mathrm{kg}$ of soil as a complete soil sample, marked as A20, 40, 60, 80, 100, B20, 40, 60, 80, and 100, C20, 40, 60, 80, 100, D20, 40, 60, 80, and 100. Each complete soil sample was divided into two portions, one for air drying, grinding to pass through 100-mesh sieve, and measuring heavy metal content. The other was stored at $4{ }^{\circ} \mathrm{C}$ before analyzed soil biochemical properties.

\subsection{Sampling analysis}

The five fractions of $\mathrm{Cd}, \mathrm{Cr}$, and $\mathrm{Pb}$ were extracted by Tessier SER. The concentration of heavy metals was measured by an inductively coupled plasma mass spectroscopy (ICPMS) (Tessier et al., 1979). Soil moisture was determined

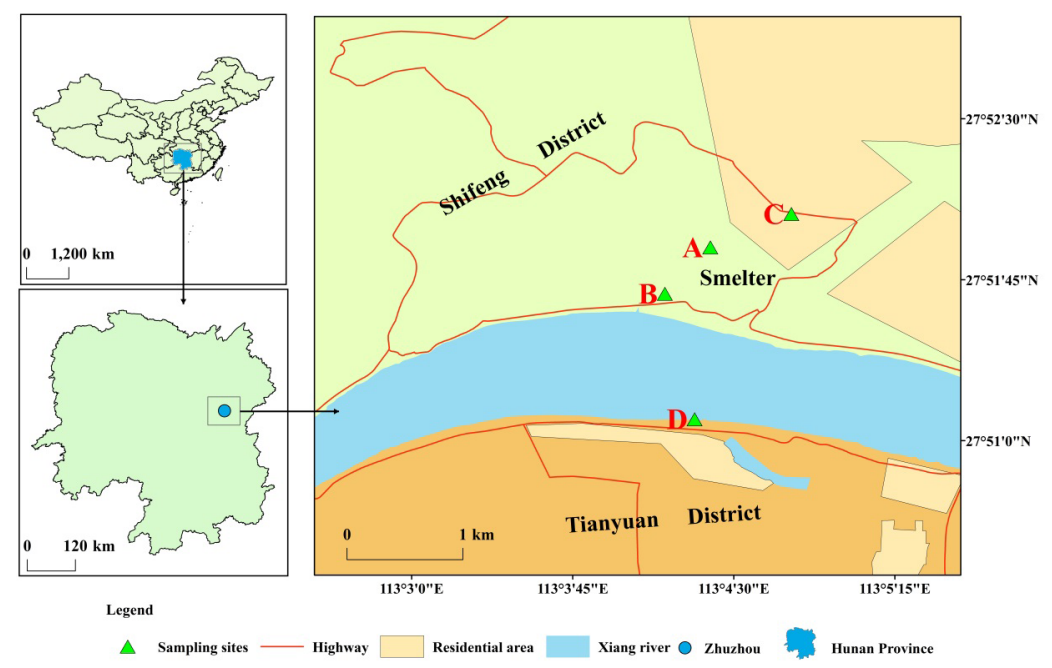

Figure 1. Four sampling sites. A: $113^{\circ} 4^{\prime} 23.46^{\prime \prime} \mathrm{E}, 27^{\circ} 51^{\prime} 54.03^{\prime \prime} \mathrm{N}, \mathrm{B}: 113^{\circ} 4^{\prime} 10.74^{\prime \prime} \mathrm{E}$, $27^{\circ} 51^{\prime} 41.06^{\prime \prime} \mathrm{N}, \mathrm{C}: 113^{\circ} 4^{\prime} 46.09^{\prime \prime} \mathrm{E}, 27^{\circ} 52^{\prime} 3.39^{\prime \prime} \mathrm{N}$, D: $113^{\circ} 4^{\prime} 19.06^{\prime \prime} \mathrm{E}, 27^{\circ} 51^{\prime} 5.97^{\prime \prime} \mathrm{N}$ 
using oven-drying method. Soil $\mathrm{pH}$ in soil-water (1: 2.5) suspension was measured by a $\mathrm{pH}$ meter with a composite electrode (PHSJ-4F, China). Soil organic carbon was extracted using potassium dichromate volumetric method (Xu et al., 2019). Soil available nitrogen determination was performed by the method of Dorich and Nelson (Dorich \& Nelson, 1984). The urease was extracted by sodium phenolate colorimetry, and the urease activity was detected by amount of $\mathrm{NH}_{3}-\mathrm{N}$ in soil after experimental treatment $24 \mathrm{~h}$. The catalase enzyme was obtained by measuring volume of required for $\mathrm{KMnO}_{4}$ titration after adding hydrogen peroxide to the soil for $20 \mathrm{~min}$. The dehydrogenase activity was determined using ultraviolet spectrometry method (Akhtar et al., 2018). Each experiment was replicated three times.

\subsection{Ratio of secondary phase and primary phase (RSP)}

Xia et al. (2018) proposed that primary minerals in sediments were regarded as primary phase, weathering products of primary minerals and exotic organisms as secondary phase. Ratio of secondary phase and primary phase was used to evaluate potential ecological risk of the soils and formula was as follows:

$$
R S P=M_{\text {sec }} / M_{\text {prim }}
$$

The $M_{\text {sec }}$ and $M_{\text {prim }}$ were the secondary phase and primary phase values of soils. The RSP values of the classification criteria for heavy metals are listed in Table 1.

Table 1. Classification criteria of the Ratio of secondary phase and primary phase (RSP) (Xia et al., 2018)

\begin{tabular}{|l|c|c|c|c|}
\hline Type & 1 & 2 & 3 & 4 \\
\hline$R S P$ value & $\leq 1$ & $1 \sim 2$ & $2 \sim 3$ & $>3$ \\
\hline Pollution level & clean & low & moderate & high \\
\hline
\end{tabular}

\section{Results}

\subsection{Soil properties and enzyme activity}

Soil properties and enzymes are indicators of soil biological changes, and enzymes are sensitive indicators of changes in soil properties (Kravkaz et al., 2018). The vertical distributions of soil properties and enzyme activities at four sampling sites are shown in Table 2. Properties of soil $\mathrm{pH}$, water contents, organic carbon, and available nitrogen were studied, and there were no significant variations for these depending on soil depth at four sampling sites. Soil $\mathrm{pH}$ shows acidity ( $\mathrm{pH}$ mean values ranging from 4.71-6.40). During the enzyme activity, three enzyme activities are not significant variations in vertical section

Table 2. The biochemical properties of soils at four sampling sites

\begin{tabular}{|c|c|c|c|c|c|c|c|}
\hline Districts & $\mathrm{pH}$ & $\begin{array}{c}\text { Water content } \\
(\%)\end{array}$ & $\begin{array}{l}\text { Organic } \\
\text { carbon } \\
(\mathrm{g} / \mathrm{kg})\end{array}$ & $\begin{array}{l}\text { Available } \\
\text { nitrogen } \\
\text { (mg/kg) }\end{array}$ & $\begin{array}{l}\text { Urease } \\
(\mathrm{mg} / \mathrm{g} . \mathrm{d})\end{array}$ & $\begin{array}{c}\text { Dehydrogenase } \\
(\mathrm{mg} / \mathrm{g})\end{array}$ & $\begin{array}{c}\text { Catalase } \\
(\mathrm{mL} / \mathrm{g} .20 \mathrm{~min})\end{array}$ \\
\hline A20 & $5.61 \pm 0.38$ & $0.20 \pm 0.01$ & $67.43 \pm 4.72$ & $84.56 \pm 5.07$ & $4.22 \pm 0.01$ & $19.23 \pm 1.65$ & $1.40 \pm 0.03$ \\
\hline A40 & $5.31 \pm 0.27$ & $0.20 \pm 0.01$ & $67.03 \pm 4.69$ & $82.88 \pm 4.97$ & $4.18 \pm 0.01$ & $17.02 \pm 1.20$ & $2.40 \pm 0.19$ \\
\hline A60 & $5.34 \pm 0.37$ & $0.16 \pm 0.00$ & $68.47 \pm 4.79$ & $66.98 \pm 4.01$ & $4.33 \pm 0.01$ & $12.60 \pm 0.89$ & $2.30 \pm 0.18$ \\
\hline A80 & $5.20 \pm 0.26$ & $0.20 \pm 0.01$ & $70.38 \pm 4.93$ & $75.35 \pm 4.52$ & $4.25 \pm 0.00$ & $15.97 \pm 1.13$ & $2.48 \pm 0.20$ \\
\hline A100 & $5.59 \pm 0.28$ & $0.23 \pm 0.01$ & $69.67 \pm 4.88$ & $71.16 \pm 4.26$ & $4.31 \pm 0.00$ & $13.12 \pm 2.20$ & $1.00 \pm 0.01$ \\
\hline B20 & $5.06 \pm 0.25$ & $0.15 \pm 0.00$ & $67.67 \pm 3.23$ & $77.86 \pm 6.23$ & $4.37 \pm 0.00$ & $36.60 \pm 1.56$ & $2.40 \pm 0.08$ \\
\hline B40 & $5.98 \pm 0.30$ & $0.19 \pm 0.00$ & $68.79 \pm 9.34$ & $78.70 \pm 6.30$ & $4.44 \pm 0.00$ & $41.65 \pm 7.89$ & $2.15 \pm 0.17$ \\
\hline $\mathrm{B} 60$ & $6.40 \pm 0.32$ & $0.27 \pm 0.01$ & $69.19 \pm 9.99$ & $64.46 \pm 5.16$ & $4.31 \pm 0.03$ & $29.86 \pm 3.23$ & $2.25 \pm 0.12$ \\
\hline B80 & $6.04 \pm 0.30$ & $0.22 \pm 0.01$ & $66.71 \pm 5.67$ & $81.25 \pm 7.30$ & $4.12 \pm 0.01$ & $23.23 \pm 4.34$ & $0.45 \pm 0.12$ \\
\hline B100 & $6.38 \pm 0.32$ & $0.16 \pm 0.01$ & $69.75 \pm 8.67$ & $66.98 \pm 5.39$ & $4.27 \pm 0.01$ & $24.60 \pm 1.74$ & $0.55 \pm 0.03$ \\
\hline $\mathrm{C} 20$ & $5.28 \pm 0.26$ & $0.14 \pm 0.00$ & $58.97 \pm 9.56$ & $70.32 \pm 1.41$ & $4.30 \pm 0.00$ & $27.44 \pm 1.24$ & $0.15 \pm 0.00$ \\
\hline $\mathrm{C} 40$ & $4.85 \pm 0.24$ & $0.16 \pm 0.00$ & $59.46 \pm 3.21$ & $74.51 \pm 1.49$ & $4.32 \pm 0.01$ & $35.96 \pm 2.55$ & $0.50 \pm 0.00$ \\
\hline C60 & $4.73 \pm 0.23$ & $0.14 \pm 0.00$ & $69.43 \pm 2.34$ & $68.65 \pm 1.37$ & $4.13 \pm 0.01$ & $23.33 \pm 1.66$ & $0.70 \pm 0.00$ \\
\hline $\mathrm{C} 80$ & $5.15 \pm 0.11$ & $0.23 \pm 0.01$ & $66.63 \pm 2.90$ & $66.14 \pm 1.32$ & $4.22 \pm 0.01$ & $18.91 \pm 1.34$ & $1.20 \pm 0.01$ \\
\hline $\mathrm{C} 100$ & $4.71 \pm 0.00$ & $0.16 \pm 0.00$ & $82.67 \pm 7.89$ & $77.02 \pm 3.54$ & $4.27 \pm 0.00$ & $23.12 \pm 1.64$ & $2.45 \pm 1.20$ \\
\hline $\mathrm{D} 20$ & $4.76 \pm 0.24$ & $0.25 \pm 0.01$ & $35.51 \pm 0.71$ & $62.79 \pm 1.23$ & $4.21 \pm 0.01$ & $25.97 \pm 1.33$ & $0.35 \pm 0.00$ \\
\hline $\mathrm{D} 40$ & $4.38 \pm 0.23$ & $0.25 \pm 0.01$ & $40.30 \pm 0.80$ & $74.51 \pm 1.49$ & $4.26 \pm 0.02$ & $25.65 \pm 1.82$ & $0.45 \pm 0.01$ \\
\hline D60 & $4.85 \pm 0.01$ & $0.24 \pm 0.01$ & $38.78 \pm 0.77$ & $77.86 \pm 1.56$ & $4.25 \pm 0.04$ & $23.76 \pm 1.69$ & $0.30 \pm 0.00$ \\
\hline D80 & $4.23 \pm 0.36$ & $0.21 \pm 0.01$ & $46.28 \pm 0.92$ & $77.86 \pm 1.45$ & $4.38 \pm 0.06$ & $22.28 \pm 1.58$ & $0.40 \pm 0.00$ \\
\hline D100 & $4.97 \pm 0.25$ & $0.20 \pm 0.01$ & $38.78 \pm 0.77$ & $79.53 \pm 1.59$ & $4.25 \pm 0.01$ & $19.86 \pm 0.01$ & $0.60 \pm 0.00$ \\
\hline
\end{tabular}

Note: A, B, C, and D represent four sampling sites. 20, 40, 60, 80, and 100 represent 20-100 cm of soil depth, respectively. 


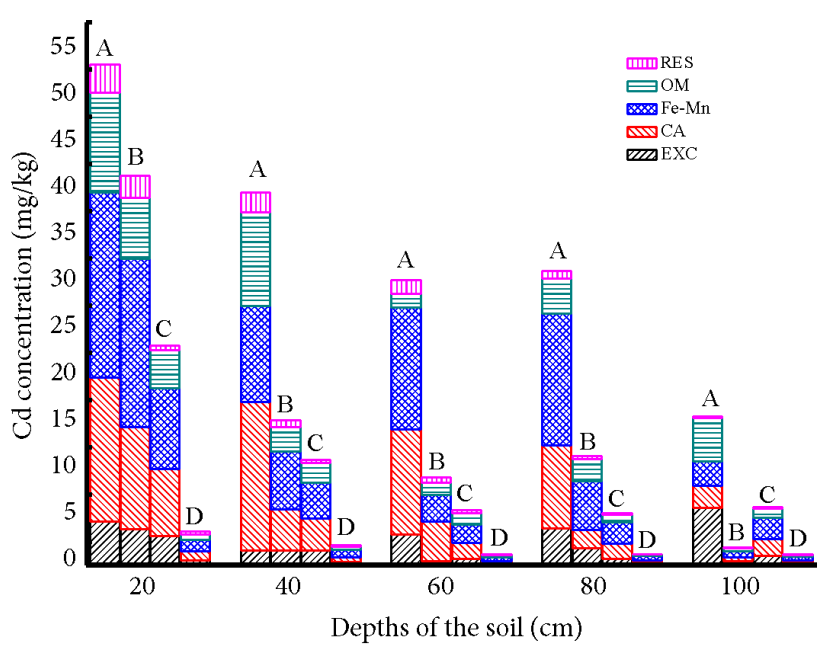

a) Distribution of heavy metal Cd

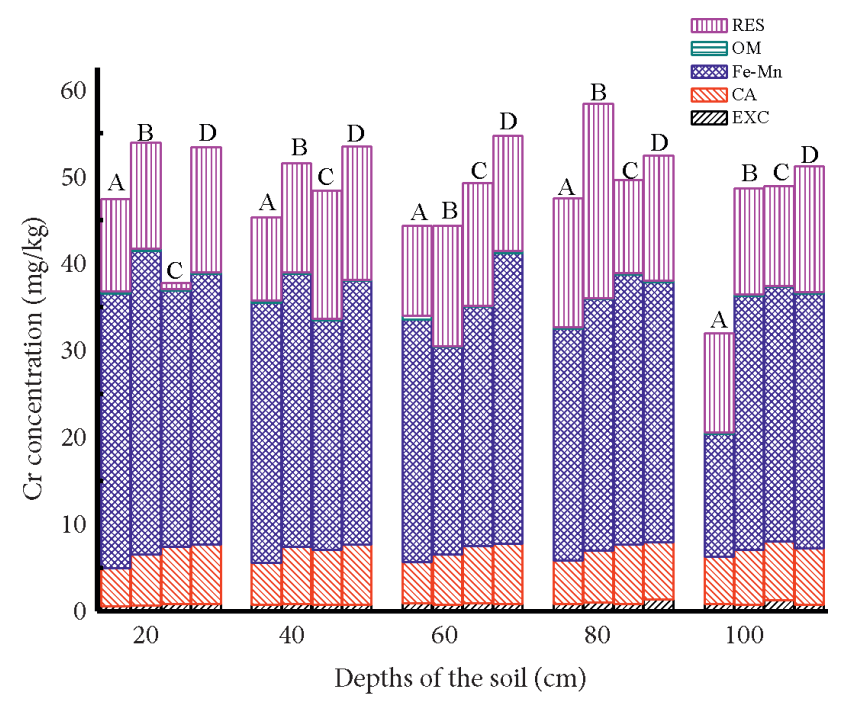

b) Distribution of heavy metal Cr

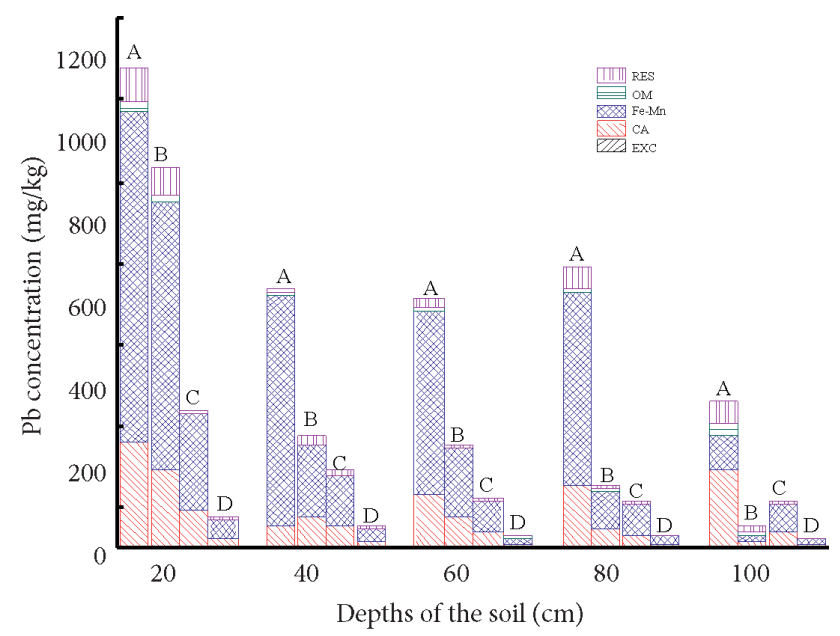

c) Distribution of heavy metal $\mathrm{Pb}$

Figure 2. Distributions of three heavy metals at different depths in soil. EXC: exchangeable fraction, CA: carbonate fraction, Fe-Mn: Fe-Mn oxide fraction, OM: organic matter fraction, RES: residual fraction at four sampling sites. But dehydrogenase and catalase enzyme are differences among four sampling sites, and mean values ranging from $15.58-31.18 \mathrm{mg} / \mathrm{g}$ and $0.42-$ $1.91 \mathrm{~mL} / \mathrm{g} .20 \mathrm{~min}$.

\subsection{Distribution of heavy metals fraction}

The heavy metal $\mathrm{Cd}, \mathrm{Cr}$, and $\mathrm{Pb}$ were extracted by using the Tessier SER in this study. Heavy metal fractions include exchangeable fraction (EXC), carbonate fraction (CA), $\mathrm{Fe}-\mathrm{Mn}$ oxide fraction ( $\mathrm{Fe}-\mathrm{Mn})$, organic matter fraction (OM), and residual fraction (RES). In general, CA and EXC fractions are easy to be utilized by living organisms, Fe-Mn fraction is unstable under low potential conditions, and RES and OM fractions of heavy metal could hardly be utilized and have minimal environmental impact (Huang et al., 2018; Rong et al., 2020).Vertical distributions of heavy metal fraction in four sampling sites of smelter are shown in Figure 2. In general, $\mathrm{Cd}$ and $\mathrm{Pb}$ contents decrease with depth of soil, and they follow order of $A>B>C>D$ in the vertical section at the four sampling sites except $100 \mathrm{~cm}(A>C>B>D)$, while amount of $C r$ is no significant variation (minimum at $100 \mathrm{~cm}$ in A site is $31.93 \mathrm{mg} / \mathrm{kg}$ ). The major fraction of $\mathrm{Cd}$ is Fe-Mn and $\mathrm{CA}$ at different depths of four sampling sites, excepting $100 \mathrm{~cm}$ in A site (the major fraction is EXC and accounted for $38.28 \%$ of total cadmium), while the major fraction of $\mathrm{Cr}$ is $\mathrm{Fe}-\mathrm{Mn}$ and RES. For $\mathrm{Pb}$, the major fraction is Fe-Mn at different depths of four sampling sites.

Figure 3 is the principal component analysis (PCA) of five fractions of $\mathrm{Cd}$ and $\mathrm{Pb}$. The values of KMO in Figure 3 $(\mathrm{a}-\mathrm{b})$ are 0.679 and 0.672 , respectively, and their Bartlett's Test $\mathrm{p}$ values are less than 0.05 , and their KolmogorovSmirnov test $\mathrm{p}$ values are less than 0.05 . These tests show principal component analysis is suitable for the study. The Figure $3(a-b)$ shows that cumulative variance of contributions reach $93.58 \%$ and $90.19 \%$ for principal component of $\mathrm{Cd}$, and $\mathrm{Pb}$, respectively. The EXC fraction of $\mathrm{Cd}$ is clustered to one component accounting for $82.74 \%$ of variance, and the rest to second component accounting for $10.84 \%$ of variance. This is also same situation with $\mathrm{Pb}$, and two component accountiong for $70.00 \%$ and $20.19 \%$ of variance, respectively. The analysis reveals that fractions of $\mathrm{Cd}$ and $\mathrm{Pb}$ are highly correlated, except for EXC fraction. For heavy metal $\mathrm{Cr}$, the value of $\mathrm{KMO}$ is 0.333 , and it's not suitable for principal component analysis. This also shows that five fractions of $\mathrm{Cr}$ have low correlation.

\subsection{Correlation analysis}

In order to explore the interaction between heavy metals in soil, this study analyzed correlation of five fractions of three heavy metals. The results are given in Table 3. There is a positive correlation between five fractions of $\mathrm{Cd}$ $(0.54<\mathrm{r}<0.92)$, and they are positively correlated with CA, Fe-Mn, RES, and OM fractions of $\mathrm{Pb}(0.55<\mathrm{r}<0.96)$. A significant positive correlation is observed between $\mathrm{Cd}$ fraction and $\mathrm{OM}$ fraction of $\mathrm{Cr}(0.46<\mathrm{r}<0.78)$ and a negative correlation $(-0.70<\mathrm{r}<-0.82)$ with CA fraction of $\mathrm{Cr}$. 


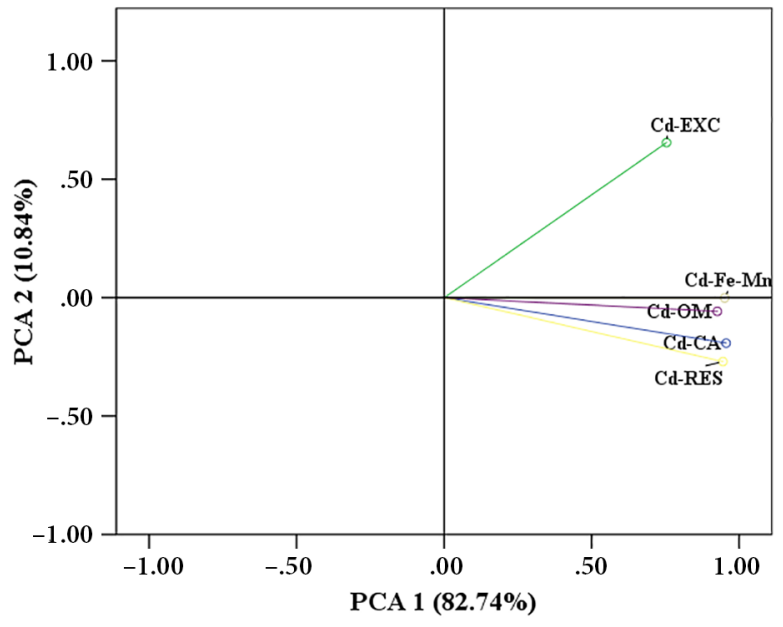

a) Principal component analysis of Cd fraction

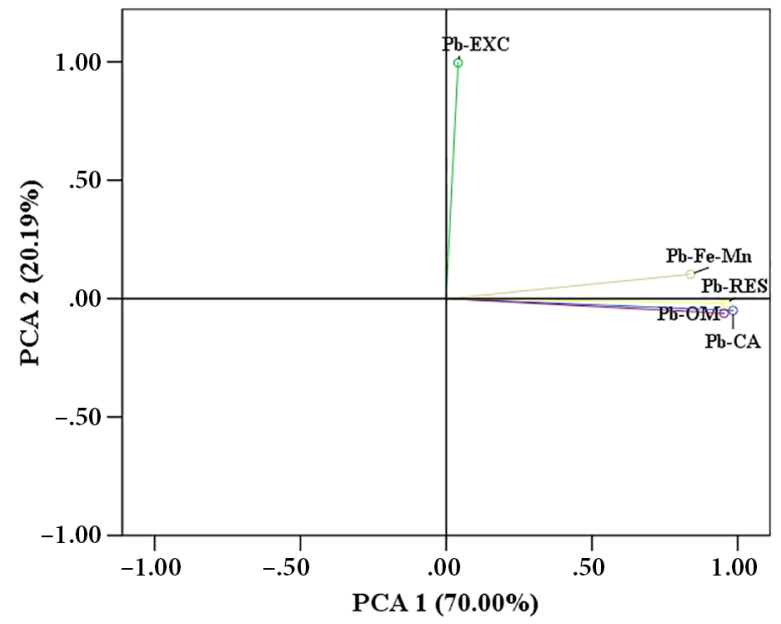

b) Principal component analysis of $\mathrm{Pb}$ fraction

Figure 3. Principal component analysis of heavy metal $\mathrm{Pb}$ and $\mathrm{Cd}$ fractions. EXC: exchangeable fraction, CA: carbonate fraction, Fe-Mn: Fe-Mn oxide fraction, OM: organic matter fraction, RES: residual fraction

Among five fractions of $\mathrm{Cr}$, only $\mathrm{CA}$ and $\mathrm{OM}$ fractions are correlated significantly. CA fraction is negatively $(-0.64<\mathrm{r}<-0.79)$ correlate with CA, Fe-Mn, RES, and $\mathrm{OM}$ fractions of $\mathrm{Pb}$. However, $\mathrm{OM}$ fraction is positively correlate with $\mathrm{CA}, \mathrm{Fe}-\mathrm{Mn}$, and $\mathrm{OM}$ fractions of $\mathrm{Pb}$ $(0.45<\mathrm{r}<0.74)$ and low correlation with RES fraction of $\mathrm{Pb}$. This result also explains why KOM value is low in $\mathrm{Cr}$.

With regard to $\mathrm{Pb}$, except for EXC fraction, other fractions are significantly correlated $(0.65<\mathrm{r}<0.95)$. In addition, the correlation between heavy metals and soil depths are presented in Table 3. These results indicate that $\mathrm{Cd}$ and $\mathrm{Pb}$ were significantly negative correlations with soil depths except RES fraction of $\mathrm{Pb}$. On the contrary, $\mathrm{Cr}$ and soil depths are less relevant.

Heat map is a well-organized method of imaging multipart data sets prepared as matrices, and determining relationship between variables and clusters of variables by cluster analysis (Kükrer et al., 2015). The heat map for trace elements and soil characteristics are shown in Figure 4. Figure 4 display three clusters: (1)

Table 3. Correlation matrix between five fractions of different heavy metal

\begin{tabular}{|c|c|c|c|c|c|c|c|c|c|c|c|c|c|c|c|c|}
\hline Fraction & $\begin{array}{l}\text { Cd- } \\
\text { EXC }\end{array}$ & $\begin{array}{l}\mathrm{Cd}- \\
\mathrm{CA}\end{array}$ & $\begin{array}{c}\mathrm{Cd}-\mathrm{Fe}- \\
\mathrm{Mn}\end{array}$ & $\begin{array}{l}\mathrm{Cd}- \\
\mathrm{OM}\end{array}$ & $\begin{array}{l}\text { Cd- } \\
\text { RES }\end{array}$ & $\begin{array}{c}\text { Cr- } \\
\text { EXC }\end{array}$ & $\begin{array}{l}\mathrm{Cr}- \\
\mathrm{CA}\end{array}$ & $\begin{array}{c}\mathrm{Cr}-\mathrm{Fe}- \\
\mathrm{Mn}\end{array}$ & $\begin{array}{l}\mathrm{Cr}- \\
\mathrm{OM}\end{array}$ & $\begin{array}{l}\text { Cr- } \\
\text { RES }\end{array}$ & $\begin{array}{l}\mathrm{Pb}- \\
\mathrm{EXC}\end{array}$ & $\begin{array}{l}\mathrm{Pb}- \\
\mathrm{CA}\end{array}$ & $\begin{array}{c}\mathrm{Pb}-\mathrm{Fe}- \\
\mathrm{Mn}\end{array}$ & $\begin{array}{l}\mathrm{Pb}- \\
\mathrm{OM}\end{array}$ & $\begin{array}{l}\mathrm{Pb}- \\
\mathrm{RES}\end{array}$ & Depths \\
\hline Cd-EXC & 1 & $0.59^{* *}$ & $0.70^{* *}$ & $0.65^{* *}$ & $0.54^{*}$ & -0.24 & $-0.70^{* *}$ & -0.41 & $0.46^{*}$ & -0.29 & -0.13 & $0.92^{* *}$ & $0.63^{* *}$ & $0.94^{* *}$ & $0.83^{* *}$ & $-0.53^{\star}$ \\
\hline $\mathrm{Cd}-\mathrm{CA}$ & & 1 & $0.91^{* *}$ & $0.87^{* *}$ & $0.92^{* *}$ & -0.37 & $-0.82^{* *}$ & 0.13 & $0.78^{* *}$ & -0.39 & 0.06 & $0.70^{* *}$ & $0.96^{* *}$ & $0.55^{*}$ & $0.56^{* *}$ & $-0.58^{* \star}$ \\
\hline $\begin{array}{l}\text { Cd-Fe- } \\
\mathrm{Mn}\end{array}$ & & & 1 & $0.78^{* *}$ & $0.90^{* *}$ & -0.37 & $-0.75^{* *}$ & 0.20 & $0.71^{* *}$ & -0.27 & 0.02 & $0.83^{* *}$ & $0.96^{* *}$ & $0.68^{* *}$ & $0.74^{* *}$ & $-0.58^{* *}$ \\
\hline Cd-OM & & & & 1 & $0.87^{* *}$ & -0.40 & $-0.73^{* *}$ & 0.01 & $0.56^{* *}$ & -0.33 & 0.13 & $0.72^{* *}$ & $0.86^{* *}$ & $0.67^{* *}$ & $0.65^{* *}$ & $-0.54^{*}$ \\
\hline Cd-RES & & & & & 1 & $-0.45^{*}$ & $-0.73^{* *}$ & 0.27 & $0.75^{* *}$ & -0.23 & 0.20 & $0.72^{* *}$ & $0.96^{* *}$ & $0.61^{* *}$ & $0.68^{* *}$ & $-0.50^{*}$ \\
\hline Cr-EXC & & & & & & 1 & 0.25 & -0.09 & -0.31 & 0.17 & -0.27 & -0.383 & -0.42 & -0.33 & -0.41 & 0.26 \\
\hline Cr-CA & & & & & & & 1 & 0.28 & $-0.64^{* *}$ & 0.08 & .032 & $-0.75^{* *}$ & $-0.79^{* *}$ & $-0.67^{* *}$ & $-0.64^{* *}$ & 0.50 \\
\hline $\begin{array}{l}\text { Cr-Fe- } \\
\mathrm{Mn}\end{array}$ & & & & & & & & 1 & 0.25 & -0.02 & 0.29 & -0.24 & 0.20 & -0.35 & -0.13 & 0.18 \\
\hline Cr-OM & & & & & & & & & 1 & -0.34 & 0.16 & $0.51^{*}$ & $0.74^{* *}$ & $0.45^{*}$ & 0.44 & -0.32 \\
\hline Cr-RES & & & & & & & & & & 1 & 0.10 & -0.26 & -0.29 & -0.20 & -0.08 & 0.31 \\
\hline $\mathrm{Pb}-\mathrm{EXC}$ & & & & & & & & & & & 1 & -0.01 & 0.09 & -0.01 & 0.03 & 0.42 \\
\hline $\mathrm{Pb}-\mathrm{CA}$ & & & & & & & & & & & & 1 & $0.79^{* *}$ & $0.95^{* *}$ & $0.92^{* *}$ & $-0.56^{* *}$ \\
\hline $\begin{array}{l}\mathrm{Pb}-\mathrm{Fe}- \\
\mathrm{Mn}\end{array}$ & & & & & & & & & & & & & 1 & $0.65^{* *}$ & $0.71^{* *}$ & $-0.54^{*}$ \\
\hline $\mathrm{Pb}-\mathrm{OM}$ & & & & & & & & & & & & & & 1 & $0.93^{* *}$ & $-0.44^{*}$ \\
\hline Pb-RES & & & & & & & & & & & & & & & 1 & -0.41 \\
\hline
\end{tabular}

Note: ${ }^{\star}$ represent significantly different at $\mathrm{P}<0.05$, ${ }^{* \star}$ represent significantly different at $\mathrm{P}<0.01$, EXC: exchangeable fraction, $\mathrm{CA}$ : carbonate fraction, Fe-Mn: Fe-Mn oxides fraction, OM: organic matter fraction, RES: residual fraction. 


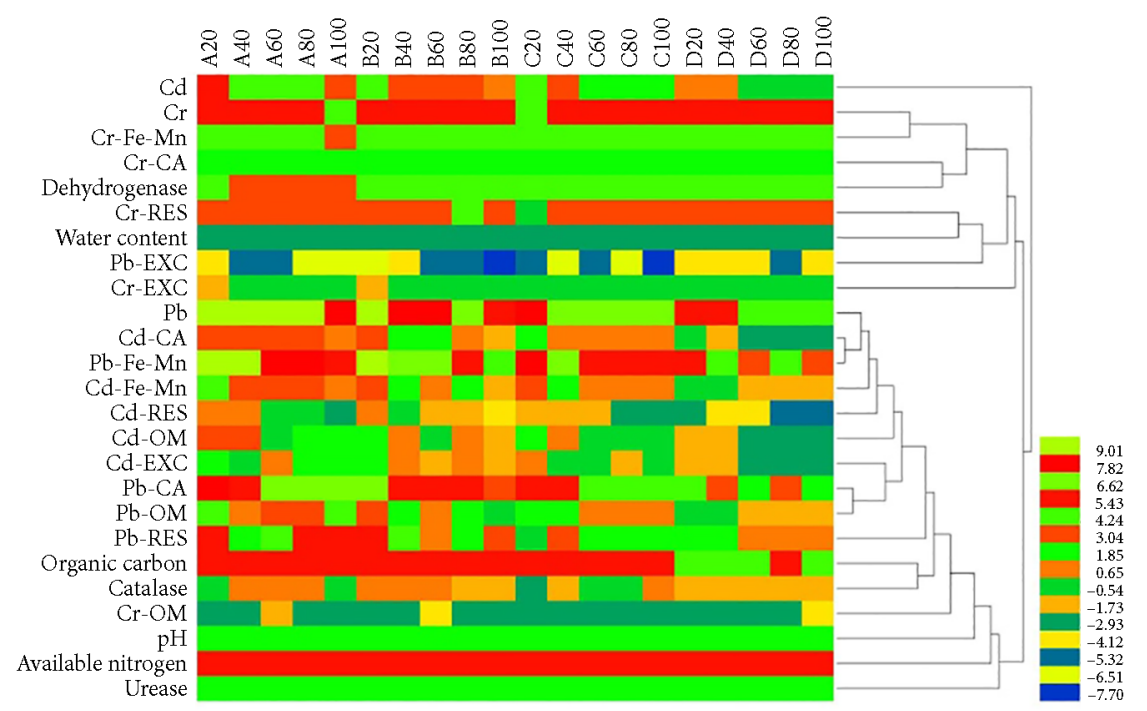

Figure 4. Hierarchical clustering analysis of trace elements and soil characteristics at four sampling sites. EXC: exchangeable fraction, CA: carbonate fraction, Fe-Mn: Fe-Mn oxides fraction, OM: organic matter fraction, RES: residual fraction.

A, B, C, and D are sampling sites. 20, 40, 60, 80, and 100 are soil depths

Total Cd. (2) Total Cr, Pb-EXC, dehydrogenase, water content, and $\mathrm{Cr}$ fraction (except $\mathrm{Cr}-\mathrm{OM}$ ), and these elements are mainly geogenic background sources. (3) Total $\mathrm{Pb}, \mathrm{Cr}-\mathrm{OM}$, enzyme activity (except dehydrogenase), organic carbon, available nitrogen, $\mathrm{pH}$, and $\mathrm{Cd}$ and $\mathrm{Pb}$ fractions (except $\mathrm{Pb}-\mathrm{EXC}$ ), and these elements may be derived from anthropogenic activity. $\mathrm{Cd}$ and $\mathrm{Pb}$ fractions are clustered together, which indicate a common source of migration (Xia et al., 2018). The results are consistent with correlation matrix and principal component analysis.

\subsection{Ratio of secondary phase and primary phase (RSP) analysis}

The chemical speciation information is of fundamental importance for practical environmental risk assessment of soil associated with heavy metals (Zhang et al., 2017). In this study, RSP evaluated intensity of human activities on soil. The RSP indices of three heavy metals are given in Figure 5. For Cd (Figure 5a), the RSP values are between 13.05 and 54.28 , which the $R S P$ values are over 3 , so the soil is heavily contaminated with $\mathrm{Cd}$ at the four sampling sites. The average $R S P$ values for $\mathrm{Cd}$ of four sampling sites follow the order of $\mathrm{C}>\mathrm{A}>\mathrm{B}>\mathrm{D}$. For $\mathrm{Cr}$ (Figure $5 \mathrm{~b}$ ), the $R S P$ values range from 1-4 except for 52.33 in the site $C 20 \mathrm{~cm}$, of which $45 \%, 45 \%$ and $10 \%$ of soil samples are serious, moderate and low pollution levels. For Pb (Figure 5c), its pollution trend is similar to $\mathrm{Cd}$ at four sampling sites, but its $R S P$ value is less than $\mathrm{Cd}$. The values of $R S P$ are higher than 4, and maximum was 16.11 at $20 \mathrm{~cm}$ in the site $\mathrm{C}$. The Figure 5 shows that $R S P$ values of $\mathrm{Cd}$ and $\mathrm{Pb}$ decreases with the depth of soil at the sites A, B, C, and $D$. The RSP value of Cr has no obvious change in depth of soil, while it is too high in the site C $20 \mathrm{~cm}$ of. These results are consistent with total heavy metal analysis except for RSP assess soil was pollution with Cr. It confirms that soil may suffer anthropogenic activity, resulting in higher calculated $R S P$ value.

\section{Discussion}

The soil $\mathrm{pH}$ is affected by heavy metal, smelting waste, and geographic locations (Lenart \& Wolny-Koladka, 2013). In this study, the soils of four sampling sites were acidic. The primary cause was that the soil of South China was affected by acidic rainfalls and this smelter often discharges acidic wastewater, waste gas (Wang \& Wang, 1995). Interestingly, the available nitrogen and organic carbon contents were very high, but the soil enzyme activity was lower. The possible reason was that soil microorganisms might exhibit metabolic dysfunction under smelting waste stress (Gupta \& Diwan, 2017). The biomass was less effective in mineralised organic matter under metal stress, resulting in high organic carbon content (Valsecchi et al., 1995). Additionally, soil properties and enzyme activities were no significant change in the vertical section at different districts, similar conclusion were drawn by most of the studies (Beattie et al., 2017). In general, soil biochemical properties may have been altered under this smelter discharge of smelting waste will require further research on soil (Zhang et al., 2011; Shen et al., 2018).

The topsoil of the smelter is susceptible to anthropogenic activity, resulting in heavy metals contents increase (Sun \& Mou, 2016). In addition, heavy metals contents in soil around a smelter vary with the different sites (Shen et al., 2017). Therefore, soil profile was studied from 0 to $100 \mathrm{~cm}$ at the four sampling sites of smelter in this 


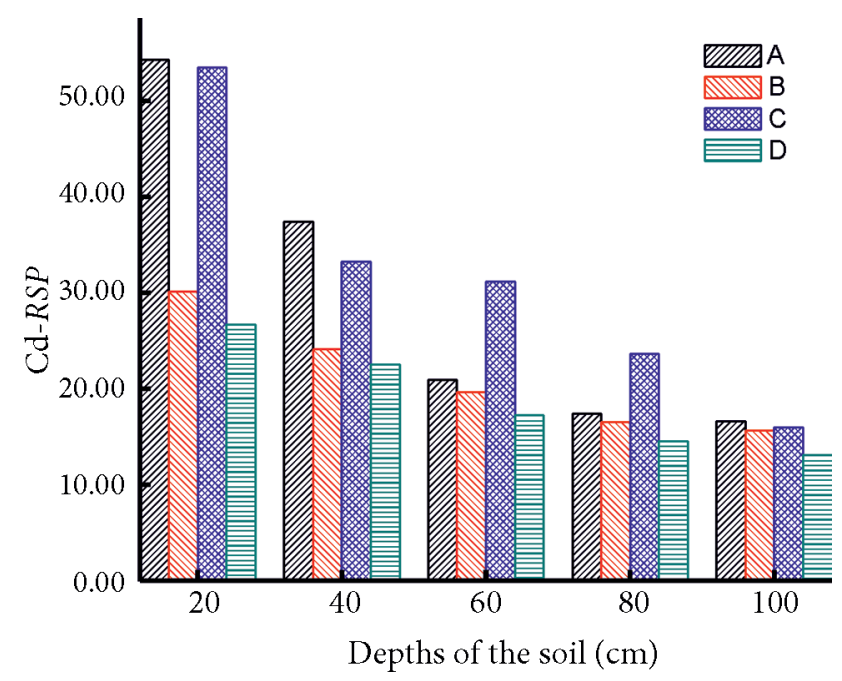

a) The value $R S P$ of $\mathrm{Cd}$

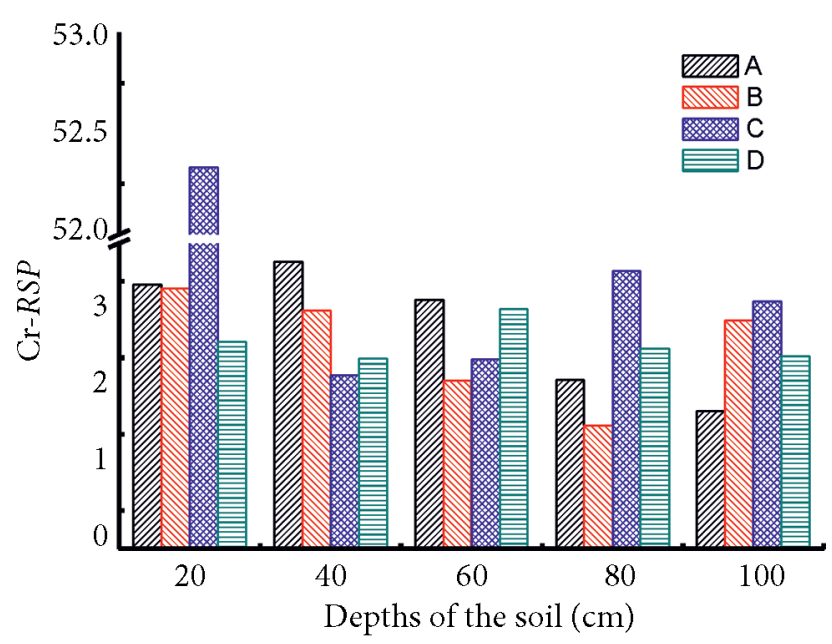

b) The value $R S P$ of $\mathrm{Cr}$

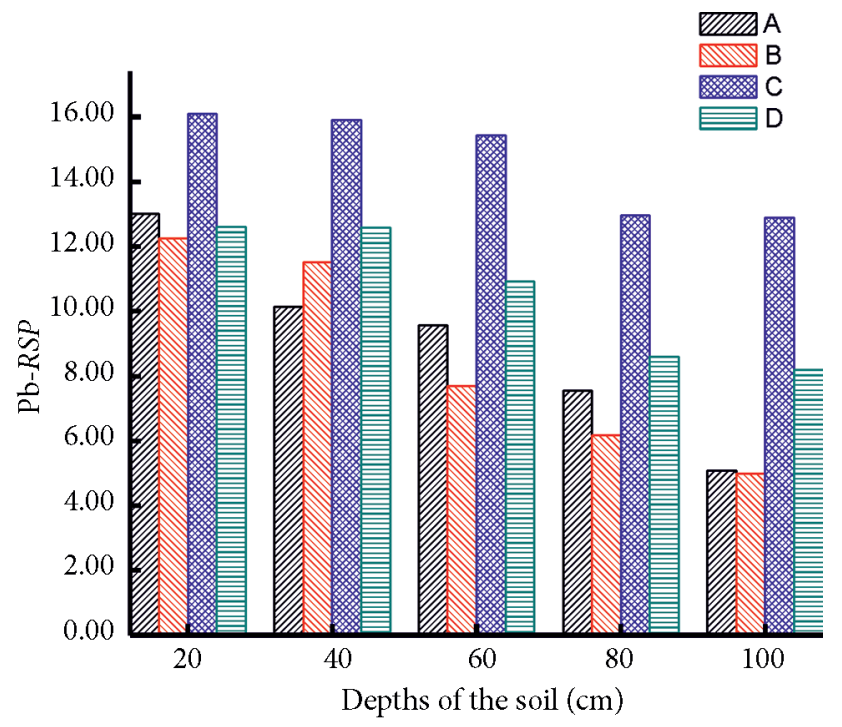

c) The value $R S P$ of $\mathrm{Pb}$

Figure 5. RSP of three heavy metals at different depths in the soils study. The results indicated that total Cd content of all sampling soils exceeded secondary standard maximum allowable value of environmental quality standard for soil (GB15618-1995) (Cui et al., 2018). On the contrary, total $\mathrm{Cr}$ content did not exceed by the concentration limit. Total $\mathrm{Pb}$ content did not exceed the concentration limit in site B $60-100 \mathrm{~cm}$ and sites A $40-100 \mathrm{~cm}$ and C, possibly due to it had allochthonous origins, such as through surface runoff and industrial drainage (Kükrer, 2018). The amounts of total $\mathrm{Cd}$ and $\mathrm{Pb}$ were decreased with depth of the soil. Shen et al. (2017) explored soil near a Pb/Zn smelter, the results show that soil $\mathrm{Cd}$ and $\mathrm{Zn}$ contents decreased vertically. Sun et al. (2013) surveyed spatial distribution of heavy metals in agricultural soil, $\mathrm{Cu}$ and $\mathrm{Pb}$ were negative correlation with soil depths. Strangely, the total $\mathrm{Cr}$ amount had no significant change in the soil depth. In brief, the soil suffered $\mathrm{Cd}$ and $\mathrm{Pb}$ multiple polloution, and heavy metal $\mathrm{Cr}$ existed in an extremely stable form.

In this study, at different depths, three heavy metals were dominated by Fe-Mn fraction, except for a few cases. Possible reason was that the soil was subject to severe emission of metal ion-containing wastewater and soild waste (Ye et al., 2019). A large number of metal ions were present in soil, which will promote formation of Fe-Mn fraction (Zhong et al., 2014). At different sampling sites, all fractions of $\mathrm{Cd}$ and $\mathrm{Pb}$ followed the order of $\mathrm{A}>\mathrm{B}>\mathrm{C}>\mathrm{D}$, but site $C$ fraction exceed site $B$ in $100 \mathrm{~cm}$, reason was that site B soil was tighter than site C, resulting in heavy metal migration slowed with soil depth (Nabulo et al., 2010). The Cr fraction did not obviously change in four sites, and RSP value was extremely high in site $C 20 \mathrm{~cm}$. This means that $\mathrm{C}$ site topsoils suffered serious erosion. In general, the site A was most affected due to it was most adjacent to smelting waste site source. On the contrary, site D was farthest and was lowest affected. These results showed that the soil was severely eroded and degree of influence was related to distance of pollution source.

The heavy metals distribution in soil is affected by various factors (such as total heavy metals and chemical speciation, anthropogenic activity and geogenic background, etc.) (Huang et al., 2018). Pearson's correlation analysis can reflect the degree of influence between them. There was high correlation between $\mathrm{Cd}$ and $\mathrm{Pb}$ fractions. But EXC fraction of $\mathrm{Pb}$ was not correlated with five fractions of $\mathrm{Cd}$, and its concentration was relatively low. The principal component analysis (PCA) also showed the same result. These results could be explained if EXC fraction has been converted to other chemical fractions or most have been absorbed by local vegetation (Nabulo et al., 2010). The Cr was no correlation with other except OM and CA fractions. This indicated that $\mathrm{Cd}$ and $\mathrm{Pb}$ in the smelter soils were unstable, their chemical speciation was converted. The Cr was relatively stable, but it was potentially toxic because of the correlation between OM and CA fractions $(\mathrm{P}<0.01)$. It maybe due to the smelter was corroded by $\mathrm{Fe}$ and $\mathrm{Mn}$ ions, that they could oxidize and reduce $\mathrm{Cr}$ ion to achieve fractional transformation (Jobby 
et al., 2018). There was no doubt that transformation of heavy metal chemical fractions during heavy metal pollution in soil is inevitable (Ancona et al., 2020). Combining with source analysis and RSP assessment results shows: this smelter's anthropogenic activity was same source of $\mathrm{Cd}$ and $\mathrm{Pb}$, while heavy metal $\mathrm{Cr}$ was derived from anthropogenic activity and geogenic background.

\section{Conclusions}

In the past few years, heavy metal pollution prevention and control have made rapid progress in Zhuzhou, but this problem was still serious. Conducting field investigation and analyzing the heavy metals properties in typical contaminated areas to fully understand the process, extent, and source of heavy metal pollution will improve remediation effect. This study explored spatial distributions of three heavy metals $\mathrm{Cd}, \mathrm{Cr}$ and $\mathrm{Pb}$ in soil around Zhuzhou smelter beside Xiangjiang River, and conducted a series of analyses. From the above results, the following conclusions can be drawn: $\mathrm{Cd}$ and $\mathrm{Pb}$ contents of this smelter exceeded secondary standard maximum allowable value of Environmental quality standard for soil (GB15618-1995), while $\mathrm{Cr}$ content did not exceed. $\mathrm{Pb}, \mathrm{Cd}$ and $\mathrm{Cr}$ of this smelter were dominated by Fe-Mn fraction. The RSP assessment concluded that serious polluted by heavy metal $\mathrm{Pb}$ and $\mathrm{Cr}$, while $\mathrm{Cr}$ typically at a moderate level, except for a few cases. The correlation and cluster analysis shown that $\mathrm{Cd}, \mathrm{Pb}$, and partly $\mathrm{Cr}$ derived from anthropogenic activity, and geogenic background was $\mathrm{Cr}$ main source. It can be speculated that this smelter suffered serious anthropogenic activity (corrosion of metal ions from smelting waste), leading to heavy metal fractions transforming to Fe-Mn fraction. Therefore, this smelter should be more focused on removing metal ions from smelting waste to improve remediation efficiency.

\section{Author contributions}

Xiaoxi Zeng, Qiming Chen, and Wen Li: Conceptualization, Methodology, Software. Hong Xu, Xiaoxi Zeng, and Qiming Chen: Data curation, Writing-Original draft preparation. Jiali Ren, Feijun Luo, and Ling Wu: Visualization, Investigation. Jianxing Tang: Supervision. Dongmin Liu and Hong Xu: Software, Validation. Xiaoxi Zeng, Qiming Chen, Qing Tan, Sheng Yang, Jianhui Wang, and Yuanke Zhang: Writing-Reviewing and Editing.

\section{Acknowledgements}

This research was funded by National Science and Technology Program during the Twelfth Five-year Plan Period, China (2015BAD05B02 and 2018YFE0110200), High Technology Industry S \& T Innovation Leading Project of Hunan Province (2020NK2001), The Natural Science Foundation of Hunan Province of China (2018JJ2090 and 2020JJ4278), The National Natural Science Foundation of China (51774128 and 51774129), The Key Program of the
Hunan Provincial Department of Science and Technology (2020WK2020), Program for Science \& Technology Innovation Platform/Talents of Hunan Province (2019TP1029) and Social Development and Livelihood Program of Zhuzhou City of China (2018 and 2019).

\section{Conflict of interests}

The authors declare that there is no conflict of interest regarding the publication of this paper.

\section{References}

Akhtar, K., Wang, W., Ren, G., Khan, A., Feng, Y., \& Yang, G. (2018). Changes in soil enzymes, soil properties, and maize crop productivity under wheat straw mulching in Guanzhong, China. Soil and Tillage Research, 182, 94-102. https://doi.org/10.1016/j.still.2018.05.007

Ananya, S., \& Manan, S. (2020). Characterisation and bioremediation of wastewater: A review exploring bioremediation as a sustainable technique for pharmaceutical wastewater. Groundwater for Sustainable Development, 11, 100383. https://doi.org/10.1016/j.gsd.2020.100383

Ancona, V., Barra Caracciolo, A., Campanale, C., Rascio, I., Grenni, P., Di Lenola, M., Bagnuolo, G., \& Uricchio, V. F. (2020). Heavy metal phytoremediation of a poplar clone in a contaminated soil in southern Italy. Journal of Chemical Technology \& Biotechnology, 95(4), 940-949.

https://doi.org/10.1002/jctb.6145

Beattie, R. E., Henke, W., Davis, C., Mottaleb, M. A., Campbell, J. H., \& McAliley, L. R. (2017). Quantitative analysis of the extent of heavy-metal contamination in soils near Picher, Oklahoma, within the Tar Creek Superfund Site. Chemosphere, 172, 89-95. https://doi.org/10.1016/j.chemosphere.2016.12.141

Cai, L., Xu, Z., Bao, P., He, M., Dou, L., Chen, L., Zhou, Y., \& Zhu, Y. G. (2015). Multivariate and geostatistical analyses of the spatial distribution and source of arsenic and heavy metals in the agricultural soils in Shunde, Southeast China. Journal of Geochemical Exploration, 148, 189-195. https://doi.org/10.1016/j.gexplo.2014.09.010

Cao, C., Wang, L., Li, H., Wei, B., \& Yang, L. (2018). Temporal variation and ecological risk assessment of metals in soil nearby a $\mathrm{Pb}(-) \mathrm{Zn}$ mine in Southern China. International Journal of Environmental Research and Public Health, 15(5), 940. https://doi.org/10.3390/ijerph15050940

Cui, Z., Wang, Y., Zhao, N., Yu, R., Xu, G., \& Yu, Y. (2018). Spatial distribution and risk assessment of heavy metals in paddy soils of Yongshuyu irrigation area from Songhua River Basin, Northeast China. Chinese Geographical Science, 28(5), 797809. https://doi.org/10.1007/s11769-018-0991-1

Dong, W. Q. Y., Cui, Y., \& Liu, X. (2010). Instances of soil and crop heavy metal contamination in China. Soil and Sediment Contamination: An International Journal, 10(5), 497-510. https://doi.org/10.1080/20015891109392

Dorich, R., \& Nelson, D. (1984). Evaluation of manual cadmium reduction methods for determination of nitrate in potassium chloride extracts of soils. Soil Science Society of America Journal, 48(1), 72-75.

https://doi.org/10.2136/sssaj1984.03615995004800010013x

Gupta, P., \& Diwan, B. (2017). Bacterial exopolysaccharide mediated heavy metal removal: a review on biosynthesis, mecha- 
nism and remediation strategies. Biotechnology Reports, 13, 58-71. https://doi.org/10.1016/j.btre.2016.12.006

Huang, D., Gui, H., Lin, M., \& Peng, W. (2018). Chemical speciation distribution characteristics and ecological risk assessment of heavy metals in soil from Sunan mining area, Anhui Province, China. Human and Ecological Risk Assessment: An International Journal, 24(6), 1694-1709.

https://doi.org/10.1080/10807039.2017.1422973

Jobby, R., Jha, P., Yadav, A. K., \& Desai, N. (2018). Biosorption and biotransformation of hexavalent chromium [Cr (VI)]: A comprehensive review. Chemosphere, 207, 255-266. https://doi.org/10.1016/j.chemosphere.2018.05.050

Kravkaz Kuscu, I., Cetin, M., Yigit, N., Savaci, G., \& Sevik, H. (2018). Relationship between enzyme activity (urease-catalase) and nutrient element in soil use. Polish Journal of Environmental Studies, 27(5), 2107-2112.

https://doi.org/10.15244/pjoes/78475

Kükrer, S. (2018). Vertical and horizontal distribution, source identification, ecological and toxic risk assessment of heavy metals in sediments of Lake Aygır, Kars, Turkey. Environmental Forensics, 19(2), 122-133.

https://doi.org/10.1080/15275922.2018.1448905

Kükrer, S., Erginal, A. E., Seker, S., \& Karabiyikoglu, M. (2015). Distribution and environmental risk evaluation of heavy metal in core sediments from Lake Cildir (NE Turkey). Environmental Monitoring and Assessment, 187(7), 453.

https://doi.org/10.1007/s10661-015-4685-1

Lenart, A., \& Wolny-Koladka, K. (2013). The effect of heavy metal concentration and soil $\mathrm{pH}$ on the abundance of selected microbial groups within ArcelorMittal Poland steelworks in Cracow. Bulletin of Environmental Contamination and Toxicology, 90(1), 85-90.

https://doi.org/10.1007/s00128-012-0869-3

Li, W., Jia, M.-X., Deng, J., Wang, J. H., Lin, Q.-L., Liu, C., Wang, S.-S., Tang, J.-X., Zeng, X.-X., Ma, L., Su, W., Liu, X.-Y., Cai, F., \& Zhou, L.-Y. (2018). Isolation, genetic identification and degradation characteristics of COD-degrading bacterial strain in slaughter wastewater. Saudi Journal of Biological Sciences, 25(8), 1800-1805.

https://doi.org/10.1016/j.sjbs.2018.08.022

Lu, C., Xi, W., Quan, X., \& Zhang, Z. (2018). Remediation of lime-free roasting chromite ore processing residue (COPR) by water leaching and pyrolysis process. Energy Sources, Part A: Recovery, Utilization, and Environmental Effects, 40(11), 1417-1425. https://doi.org/10.1080/15567036.2018.1477871

Mo, J. H., Yang, Q., Zhang, N., Zhang, W. X., Zheng, Y., \& Zhang, Z. E. (2018). A review on agro-industrial waste (AIW) derived adsorbents for water and wastewater treatment. Journal of Environmental Management, 227, 395-405.

https://doi.org/10.1016/j.jenvman.2018.08.069

Nabulo, G., Young, S. D., \& Black, C. R. (2010). Assessing risk to human health from tropical leafy vegetables grown on contaminated urban soils. The Science of Total Environment, 408(22), 5338-5351.

https://doi.org/10.1016/j.scitotenv.2010.06.034

Nagajyoti, P. C., Lee, K. D., \& Sreekanth, T. (2010). Heavy metals, occurrence and toxicity for plants: a review. Environmental Chemistry Letters, 8(3), 199-216. https://doi.org/10.1007/s10311-010-0297-8

Rong, Q., Zhong, K., Huang, H., Li, C. Z., Zhang, C. L., \& Nong, X. Y. (2020). Humic acid reduces the available cadmium, copper, lead, and zinc in soil and their uptake by tobacco.
Applied Sciences, 10(3), 1077.

https://doi.org/10.3390/app10031077

Shen, F., Liao, R., Ali, A., Mahar, A., Guo, D., Li, R., Xining, S., Awasthi, M. K., Wang, Q., \& Zhang, Z. (2017). Spatial distribution and risk assessment of heavy metals in soil near a $\mathrm{Pb} /$ Zn smelter in Feng County, China. Ecotoxicology and Environmental Safety, 139, 254-262.

https://doi.org/10.1016/j.ecoenv.2017.01.044

Shen, Q., Zhang, L., Kimirei, I. A., Wang, Z., Gao, Q., Chen, S., \& Yu, C. (2018). Vertical physicochemical parameter distributions and health risk assessment for trace metals in water columns in eastern Lake Tanganyika, Tanzania. Journal of Oceanology and Limnology, 37(1), 134-145. https://doi.org/10.1007/s00343-019-7351-6

Sun, C. Y., Liu, J. S., Wang, Y., Sun, L. Q., \& Yu, H. W. (2013). Multivariate and geostatistical analyses of the spatial distribution and sources of heavy metals in agricultural soil in Dehui, Northeast China. Chemosphere, 92(5), 517-523. https://doi.org/10.1016/j.chemosphere.2013.02.063

Sun, Z., \& Mou, X. (2016). Effects of sediment burial disturbance on macro and microelement dynamics in decomposing litter of Phragmites australis in the coastal marsh of the Yellow River estuary, China. Environmental Science and Pollution Research International, 23(6), 5189-5202. https://doi.org/10.1007/s11356-015-5756-0

Steliga, T., \& Kluk, D. (2020). Application of Festuca arundinacea in phytoremediation of soils contaminated with $\mathrm{Pb}, \mathrm{Ni}, \mathrm{Cd}$ and petroleum hydrocarbons. Ecotoxicology and Environmental Safety, 194, 110409.

https://doi.org/10.1016/j.ecoenv.2020.110409

Tessier, A., Campbell, P. G., \& Bisson, M. (1979). Sequential extraction procedure for the speciation of particulate trace metals. Analytical Chemistry, 51(7), 844-851.

https://doi.org/10.1021/ac50043a017

Valsecchi, G., Gigliotti, C., \& Farini, A. (1995). Microbial biomass, activity, and organic matter accumulation in soils contaminated with heavy metals. Biology and Fertility of Soils, 20(4), 253-259. https://doi.org/10.1007/BF00336086

Wang, W., \& Wang, T. (1995). On the origin and the trend of acid precipitation in China. Water, Air, and Soil Pollution, 85(4), 2295-2300. https://doi.org/10.1007/BF01186176

Wei, B. J., Zeng, X. X., Zhu, S. C., Yang, S. D., \& Tang, J. X. (2013). Spatial distribution and evaluation of heavy metals in the soil at the downwind direction of smelter beside Xiangjiang River. In $12^{\text {th }}$ International Symposium on East Asian Resources Recycling Technology, 12, 345-350 (in Chinese).

Wei, L., Lv, Z., Li, S., Feng, G., Li, J., Shen, K., \& Zhu, H. (2018). Application and case study of barrier technology in soil and groundwater remediation. In Y. Luo \& C. Tu (Eds.), Twenty years of research and development on soil pollution and remediation in China (pp. 799-808). Springer, Singapore. https://doi.org/10.1007/978-981-10-6029-8_49

Xia, J., Zheng, F., Tang, H., Li, J., \& Li, Y. (2018). Chemical speciation and risks of heavy metals in sediment of urban wetlands in southeastern China. Soil and Sediment Contamination: An International Journal, 28(1), 15-27. https://doi.org/10.1080/15320383.2018.1528574

Xu, Y., Seshadri, B., Bolan, N., Sarkar, B., Ok, Y. S., Zhang, W., Rumpel, C., Sparks, D., Farrell, M., Hall, T., \& Dong, Z. (2019). Microbial functional diversity and carbon use feedback in soils as affected by heavy metals. Environment Internation, 125, 478-488. https://doi.org/10.1016/j.envint.2019.01.071

Ye, C., Butler, O. M., Du, M., Liu, W., \& Zhang, Q. (2019). Spatiotemporal dynamics, drivers and potential sources of heavy 
metal pollution in riparian soils along a 600 kilometre stream gradient in Central China. Science of the Total Environment, 651, 1935-1945.

https://doi.org/10.1016/j.scitotenv.2018.10.107

Zhang, C., Liu, G., Xue, S., \& Song, Z. (2011). Rhizosphere soil microbial activity under different vegetation types on the Loess Plateau, China. Geoderma, 161(3-4), 115-125. https://doi.org/10.1016/j.geoderma.2010.12.003

Zhang, G. L., Bai, J. H., Xiao, R., Zhao, Q. Q., Jia, J., Cui, B. S., \& Liu, X. H. (2017). Heavy metal fractions and ecological risk assessment in sediments from urban, rural and reclamationaffected rivers of the Pearl River Estuary, China. Chemosphere, 184, 278-288. https://doi.org/10.1016/j.chemosphere.2017.05.155

Zhang, J., Chen, Z., Zhong, S., Wang, X., Huang, L., Chen, X., \& Yin, G. (2019). Metal (loid)s pollution characteristics and ecotoxicity evaluation in soil nearby a silver smelting yard. Environmental Earth Sciences, 78(3), 78-86. https://doi.org/10.1007/s12665-019-8073-y

Zhong, B., Liang, T., Wang, L., \& Li, K. (2014). Applications of stochastic models and geostatistical analyses to study sources and spatial patterns of soil heavy metals in a metalliferous industrial district of China. Science of the Total Environment, 490, 422-434. https://doi.org/10.1016/j.scitotenv.2014.04.127

Zhu, S. C., Tang, J. X., Zeng, X. X., Wei, B. J., Yang, S. D., \& Huang, B. (2015). Isolation of Mucor circinelloides Z4 and Mucor racemosus $\mathrm{Z} 8$ from heavy metal-contaminated soil and their potential in promoting phytoextraction with Guizhou oilseed rap. Journal of Central South University, 22(1), 88-94. https://doi.org/10.1007/s11771-015-2498-6 